УДК 347.254+347.252

DOI https://doi.org/10.51989/NUL.2021.4.5

\title{
ЗАХИСТ ПРАВ ОСІБ ВІД НЕЗАКОННОГО ВИСЕЛЕННЯ ІЗ СЛУЖБОВОГО ЖИТЛА
}

\author{
Крилевець Марина Сергіївна, \\ кандидат юридичних наук, \\ доцент кафедри правознавства \\ ВНЗ Укоопспілки «Полтавський університет економіки і торгівлі»
}

Автором розглянуто специфіку правового регулювання користування та виселення зі службового житла, права й обов'язки осіб, яким законом надано право на користування таким житлом. У статті проведено вивчення судової практики й ґрунтовний аналіз законодавчих норм щодо регулювання порядку використання спеціального житлового фонду й процедури використання службового житла. Розглянуто перелік осіб, виселення яких забороняється без надання іншого житла. У результаті проведення вивчення наукових поглядів цивілістів на поняття «службове житло» й права особи на отримання такого житла зроблено висновок, що не можна ототожнювати право особи на службове житло з правом на житло в цілому. Право на службове житло безпосередньо пов'язане з реалізацією особою ії трудових функцій і тривалістю трудових правовідносин. Розглянуто строки, протягом яких в особи є можливість звертатись до суду з негаторним позовом. Зауважено, що укладення договору найму службового житла є обов'язковою підставою для вселення в житло, тому його не укладення є суттєвим порушенням. Проведений аналіз практики національних судів України і Європейського суду з прав людини дозволяє зробити висновки щодо відсутності порушення положень Європейської конвенції про захист прав людини й основоположних свобод за умови необхідності врахування балансу між суспільними інтересами й інтересами особи, яка проживає в службовому житлі. Зроблено висновок, що в тому випадку, якщо власник вимагає звільнення службового житла в установленому законом порядку, не можна говорити про факт порушення права особи на житло.

Ключові слова: службове житло, роботодавець, службова особа, договір найму службового житла, право на житло, судова практика.

\section{Krylevets Maryna. Protection of persons' rights against illegal eviction from corporate housing}

The author considers the specifics of the legal regulation of the use and eviction from official housing, the rights and responsibilities of persons who have legally right to use such housing. The article examines the case law and a thorough analysis of the legislation on the regulation of the use of special housing and the procedure for the use of official housing. The list of persons who could not prohibited without other housing was analyzed. As a result of studying of scientific civilian's views and concept of "official housing" and the right of a person to receive such housing, was concluded that a person's right to official housing cannot be equated with the right to housing in general. The right to official housing is directly related to the implementation of a person's employment functions and the duration of employment. The terms during which a person has the opportunity to apply to the court with a negative claim are considered. It was note that the conclusion of a contract for the rental of official housing is a mandatory basis for moving into housing, so its conclusion is not a significant violation. The analysis of the practice of national courts of Ukraine and the practice of the European Court of Human Rights allows us to conclude that there is no violation of the European Convention for the Protection of Human Rights and Fundamental Freedoms on the need to take into account the balance between public interests. It was conclude that if the owner demands the release of official housing in the manner prescribed by law, it is impossible to speak of a violation of the person's right to housing.

Key words: official housing, employer, official, service rental agreement, right to housing, case law. 
Сучасне законодавство передбачає право працівника отримати службове житло на момент чинності між ним і роботодавцем трудових відносин. Проте виникає ряд проблемних питань під час реалізації вказаних прав, оскільки на практиці згаданими особами не дотримано положень законодавства повною мірою, не укладаються договори найму (оренди), що в подальшому ускладнює процес користування службовим житлом та містить ризики порушення пав обох сторін. Не менше питань виникає під час визнання осіб такими, що втратили право користуватись житловим приміщенням в судовому порядку. У науковій літературі відсутній також єдиний підхід щодо права членів сім'ї проживати в службовому житлі у випадку смерті працівника.

Проблема правового статусу службового житла була й залишається предметом дискусій у правовій доктрині. Визначення особливостей правового регулювання та правового статусу службового приміщення здійснювали О. Кармаза, В. Породько, П. Салій, Д. Харечко й інші.

Законодавче регулювання виникаючих правовідносин фактично датується 1983 роком, із моменту прийняття Житлового кодексу Української Радянської Соціалістичної Республіки (далі - ЖК УРСР). Разом із тим судова практика теж не $\epsilon$ єдиною, рішення судів суперечать один одному, що свідчить про необхідність внесення змін і перегляду законодавства в досліджуваній сфері.

Слід погодитись із думкою В. Породько, який зазначає, що в чинному законодавстві містяться лише ознаки службового житла, проте, жодним нормативно-правовим актом не передбачено його визначення. Вчений пропонує визначити службове житло як «окреме житлове приміщення або кімнату в комунальній квартирі, що відповідає санітарним і технічним вимогам, належить до державного чи громадського житлового фонду або фонду житлово-будівельних кооперативів, включене до переліку службових приміщень рішенням виконавчого органу районної, міської, районної в місті ради, призначене для заселення особами, які у зв'язку з характером їх трудових чи службових відносин повинні проживати за місцем роботи, служби або поблизу від нього, та таке, що має особливий режим надання, використання та виселення з нього наймача і членів його сім'i» $[1$, с. 29, 36].

П. Салій, розглядаючи право на житло крізь призму статті 8 Європейської конвенції про захист прав людини й основоположних свобод, зазначає, що під службовим житлом слід розуміти інше житло, яке знаходиться у власності або володінні громадян на основі договору житлового найму чи договору оренди або таке житло, в якому особа має право мешкати на законних підставах постійно або тимчасово [2, с. 111].

Д. Харечко, досліджуючи державноуправлінський механізм у сфері житлової політики, зазначає, що в Україні необхідно розробити цільові програми, спрямовані на забезпечення службовим житлом, а також створити відповідний житловий фонд [3, с. 118].

У 1988 році Рада Міністрів Української РСР прийняла Постанову № 7 «Про службові жилі приміщення». Особливість зазначеної постанови полягала у тому, що визначався перелік працівників, яким може бути надано службове житло, крім того, визначався порядок надання та користування зазначеними приміщеннями [4].

Постановою Ради Міністрів Української РСР «Про службові жилі приміщення» від 04 лютого 1988 року № 37, що $€$ чинною, затверджено Положення про порядок надання службових жилих приміщень і користування ними в Українській РСР (далі - Положення № 37).

Зазначеним Положення № 37 визначено ряд категорій осіб, хто може бути виселений із службового приміщення без надання іншого приміщення. Зокрема, згідно з пунктом 35 Положення № 37 без надання іншого жилого приміщення у випадках, зазначених у пункті 34 цього Положення, не може бути виселено: інвалідів війни й інших інвалідів з-поміж військовослужбовців, які стали інвалідами внаслідок поранення, контузії або каліцтва, що їх вони дістали під час захисту Союзу РСР (далі - СРСР) чи під час виконання інших обов'язків військової служби, або внаслідок захворювання, пов'язаного з перебуванням на фронті; учасників 
Великої Вітчизняної війни, які перебували в складі діючої армії; сім'ї військовослужбовців і партизанів, які загинули або пропали безвісти під час захисту СРСР чи під час виконання інших обов'язків військової служби; сім'ї військовослужбовців; інвалідів 3-поміж осіб рядового й начальницького складу органів Міністерства внутрішніх справ СРСР, які стали інвалідами внаслідок поранення, контузії або каліцтва, що їх вони дістали під час виконання службових обов'язків; осіб, які пропрацювали на підприємстві, в установі, організації, що надали їм службове жиле приміщення, не менш як десять років.

Законодавством визначено, що службове житло надається особі тимчасово, допоки з роботодавцем, який надав це житло, ії пов'язують трудові правовідносини. Після їх припинення службове житло має бути повернене роботодавцю для того, щоб у ньому мали можливість проживати інші працівники.

Відповідно до статті 319 Цивільного кодексу України (далі - ЦК України), власник володіє, користується, розпоряджається своїм майном на власний розсуд. Власник має право вчиняти щодо свого майна будь-які дії, які не суперечать закону [5].

Частиною першою статті 321 Цк України передбачено, що право власності $\epsilon$ непорушним. Ніхто не може бути протиправно позбавлений цього права чи обмежений у його здійсненні.

Статтею 391 ЦК України визначено, що власник майна має право вимагати усунення перешкод у здійсненні ним права користування та розпоряджання своїм майном.

Необхідно звернути увагу, що правова суть поняття «службове житло», на нашу думку, полягає в тому, щоб забезпечити належні умови для виконання конкретною особою ії службових обов'язків. Таким чином, не можна ототожнювати право на отримання службового житла із правом кожної особи на житло, що гарантовано Конституцією України.

Зокрема, іншої думки О. Кармаза, який прирівнює до соціального службове житло. Вчений зазначає, що в тому й полягає відмінність договору найму житла, яке $\epsilon$ об'єктом державної чи комунальної влас- ності, від договору найму житла з приватного житлового фонду, оскільки саме в першому випадку йдеться забезпечення «соціального» права громадян на житло [6, c. 22].

На нашу дуку, специфіка службового житла полягає в тому, що існує особлива процедура заселення, користування, а також виселення особи із займаного приміщення.

Відповідно до статті 118 ЖК Української РСР службові жилі приміщення призначаються для заселення громадянами, які у зв'язку з характером їх трудових відносин повинні проживати за місцем роботи або поблизу від нього [7].

Положеннями ЖК Української РСР також передбачено, що вселення у службове житло здійснюється на підставі спеціального ордеру, що $\epsilon$ єдиною підставою для вселення у надане жиле приміщення. Порядок користування та проживання в службовому приміщенні регулюється шляхом укладення договір найму жилого приміщення.

Слід зауважити, що учасники правовідносин досить часто пропускають процедуру укладення договору найму службового житла, про що свідчить судова практика (наприклад, справа № 199/5653/16-ц) [8].

На нашу думку, в таких випадках не можна говорити про законність виникаючих правовідносин, оскільки, виходячи з вищезазначених положень, особи можуть вважатись такими, що самовільно користуються чужим майном.

Відповідно до статті 124 ЖК УРСР в результаті припинення трудових відносини, робітники й службовці повинні бути виселенні з службового жилого приміщення з усіма особами, які з ними проживають, без надання іншого жилого приміщення.

Також статтею 125 ЖК Української РСР передбачено, що в результаті припинення трудових правовідносин з роботодавцем, за виключенням окремих чітко визначених випадків, особи повинні бути виселенні зі службового житла без надання іншого житлового приміщення. Таким чином, формулювання законодавчих норм $є$ достатньо чіткими та передбачуваними для особи, яка користувалась таким майном. 
Необхідно зазначити, що питання виселення зі службового приміщення членів сім'ї та інших осіб, які проживали разом 3 особою, якій надавалось службове житло, натепер розв'язується не однозначно. Переважно суди виходять з того, що у таких випадках право користування службовим житлом іншими особами $\epsilon$ похідним.

Так, наприклад, у постанові Верховного Суду України від 05 листопада 2014 року у справі № 6-158цс14 [9] та постанові Верховного Суду від 15 серпня 2018 року у справі № 595/1271/16-ц [10] суди касаційної інстанції дійшли висновку про те, що виникнення в членів сім'ї власника жилого будинку права на користування цим будинком $\epsilon$ похідним від виникнення у власника права власності на будинок, а отже, припинення права власності особи на будинок припиняє право членів його сім'ї на користування жилим будинком.

Також у постанові Верховного Суду від 05 липня 2018 року у справі № 489/7095/15-ц Суд встановив, що сім'я з трьох осіб - двоє дорослих і дитина, - яка проживали в спірній кімнаті гуртожитку, мали похідне право користування службовим приміщенням від права особи, якій у встановленому законом порядку виданий спеціальний ордер для проживання на період їі роботи.

Слід звернути увагу, що Верховний Суд у постанові від 05 липня 2017 року у справі № 761/15791/15-ц також чітко визначив, що закріплені в статтях 125 і 124 ЖК Української РСР гарантії не можуть бути застосовані під час вирішення спору про виселення з службового приміщення громадян, які не перебували чи не перебувають з організацією в трудових відносинах [11].

Так, у постанові Великої Палати Верховного Суду від 04 липня 2018 року у справі № 653/1096/16-ц (провадження №14-181цс18) із метою складання судової правозастосовної практики й дотримання правової визначеності судових рішень Велика Палата Верховного Суду відступивши від висновку Верховного Суду України, сформульованого в постанові від 27 січня 2016 року у справі №6-2913цс15, відповідно до якого позивач може в судовому порядку оскаржувати рішення відповідача про виселення зі службового житла протягом трьох років із моменту звільнення останнього [12].

Велика Палата Верховного Суду вважає, що навіть якщо власник службового житла не висловив вимогу звільнити це житло, проживання в ньому після припинення трудових правовідносин з роботодавцем не свідчить про законність його використання особою, якій воно було надане на час існування вказаних правовідносин. Нерухоме майно залишається у володінні власника й не може бути втраченим навіть тоді, коли цим майном неправомірно користується інша особа.

Таким чином, доки в особи є законні підстави бути власником нерухомого майна, іï право звертатись до суду з позовом про усунення перешкод у реалізації права користуватись, володіти, розпоряджатись iї майном, у тому числі й шляхом виселення, не може бути обмеженим. Отже, негаторний позов може бути пред'явлений протягом всього часу доки триває відповідне правопорушення.

Негаторний позов визначається, як позов власника, який $є$ фактичним володільцем майна, до будь-якої особи про усунення перешкод, які ця особа створює у користуванні чи розпорядженні відповідним майном. У випадку звернення Позивача з негаторним позовом, він має право вимагати усунення всіх перешкод у користуванні його майном або ж зобов'язати відповідача утриматися від вчинення дій, що можуть призвести до виникнення таких перешкод. Такий спосіб захисту переважно спрямований на попередження порушень прав та інтересів власника.

у тому випадку, коли особа, яка проживала у наданому їй службовому житлі, звільнилась або за будь-яких інших умов, коли перестали існувати правові підстави для використання вказаного виду житла, власник може вимагати усунення перешкод у користуванні та розпорядженні таким майном шляхом виселення.

Тобто, позовна заява про виселення зі службового житла $€$ негаторним та може пред'являтись протягом всього часу, доки триває відповідне правопорушення. Варто також звернути увагу, що негаторний позов пред'являється до того моменту, доки продовжується відповідне правопорушення до позовів про усунення 
перешкод у здійсненні права користування та розпорядження майном, так як, строки позовної давності в таких випадках не застосовується.

Такий же висновок викладений у постанові Касаційного цивільного суду у складі Верховного Суду від 06 березня 2018 року у справі № 607/15489/15-ц, що до негаторного позову позовна давність не застосовується, так як правопорушення $\epsilon$ таким, яке $\epsilon$ триваючим у часі, а тому такий позов пред'являється власником майна протягом всього часу, поки триває порушення [13].

У справі «Кривіцька та Кривіцький проти України» Європейський суд з прав людини (далі - ЄСПЛ) зазначив, що «згідно із законом» не лише вимагає, щоб оскаржувані дії держави мали підставу в національному законодавстві, а також повинні відповідати якості такого закону. Мається на увазі, що положення закону повинні бути достатньо чіткими у своїх термінах та передбачати зрозумілі засоби юридичного захисту проти свавільного застосування.

Зокрема, неодноразово ЄСПЛ наголошував, що втручання у право на повагу до житла має бути не лише законним, але й «необхідним у демократичному суспільстві». Таким чином, таке втручання повинно відповідати «нагальній суспільній необхідності», зокрема повинно переслідувати законну мету та бути співрозмірним.

ЄСПЛ після розгляду справи «Каракуця проти України» за заявою військовослужбовця, який проживав у кімнаті гуртожитку разом 3 іншими членами сім'ї та був звідти виселений після припинення служби у Міністерстві оборони України, дійшов висновку, що порушення статті 8 Конвенції відсутнє. Рішенням від 16 лютого 2017 року у справі ЄСПЛ указав, що втручання, на яке скаржився заявник, переслідувало легітимну мету, яка полягала у захисті інтересів економічного добробуту країни й прав інших осіб, а саме курсантів та інших військовослужбовців, які потребували житло у зв'язку зі службою [14].

Висновки. Аналізуючи судову практику, що сформувалася протягом багатьох років чинності Житлового кодексу Української РСР, можна зауважити, що суди різних інстанцій по-різному підходили до виселення працівників і членів їх сімей зі службового житла, пов'язуючи його виключно з припиненням службових відносин.

Необхідно зазначити, що питання про правомірність користування службовими приміщеннями не втратить свою актуальність до тих пір, доки існуватиме необхідність проживання працівника поблизу місця роботи. Разом із тим законодавство гарантує службове житло певним категоріям осіб у зв'язку з реалізацією ними трудових функцій. Таким чином, користування службовим житловим приміщенням працівником і його членами сім'ї залишається одним із дискусійних питань, на яке наштовхується судова практика під час вирішення спорів у випадку виселення осіб, які там проживають.

На нашу думку, особа, яка отримує службове житло, під час укладення договору найму (оренди) службового житла повинна бути ознайомлена з всіма умовами такого договору. Отже, така особа повинна самостійно в добровільному порядку звільнити жиле приміщення після припинення трудових відносин із роботодавцем. У такому випадку вказані обставини свідчать про відсутність порушеного права, навіть якщо власник вимагає звільнення приміщення та повернення його майна.

\section{ЛITEPATУРА:}

1. Породько В.В. Ознаки службового житла в контексті проблем їх законодавчого закріплення. Юридичний часопис Національної академії внутрішніх справ. 2015. № 2. С. 28-39.

2. Салій П.І. Питання недоторканності житла та іншого володіння особи в контексті Конституції та чинного законодавства України, Європейської конвенції про захист прав людини й основоположних свобод та практики Європейського суду з прав людини. Юридична наука. 2014. № 2. С. 104-112.

3. Харечко Д.О. Проблеми застосування нормативно-правового механізму щодо забезпечення житлом окремих категорій громадян. Ефективність державного управління. 2017. Вип. 1. С. 110-118. 
4. Про службові жилі приміщення : Постанова Ради Міністрів Української РСР від 4 лютого 1988 року № 37. База даних «Законодавство України». URL: https://zakon.rada.gov.ua/laws/ show/37-88-\%D0\%BF\#top.

5. Цивільний кодекс України : Закон України від 16 січня 2003 року № 435-IV / Верховна Рада України. Відомості Верховної Ради України. 2003. №№ 40-44. Ст. 356.

6. Кармаза О.О. Договір найму житла та договір оренди житла: їх співвідношення. Підприємництво, господарство і право. 2016. № 2. С. 18-23.

7. Житловий кодекс Української РСР : Закон України від 30 червня 1983 року № 5464-Х / Верховна Рада УРCP. URL: https://zakon.rada.gov.ua/laws/show/5464-10\#Tex.t

8. Рішення Амур-Нижньодніпровського районного суду м. Дніпропетровська від 05 січня 2017 року у справі 199/5653/16-ц. Єдиний державний реєстр судових рішень. URL: http://reyestr.court.gov.ua/Review/64224711.

9. Постанова Судової палати у цивільних справах Верховного Суду України від 05 листопада 2014 року у справі № 6-158цс14 / Верховний Суд України. URL: https://oda.court.gov.ua/ sud1590/pravovipoziciivsu/6-158cs14).

10. Постанова Верховного Суду від 15 серпня 2018 року у справі № 595/1271/16-ц / Верховний Суд України. URL: https://verdictum.ligazakon. net/document/75970043.

11. Постанова Верховного Суду від 05 липня 2017 року у справі № 761/15791/15-ц / Верховний Суд України. URL: https://zakononline.com.ua/court-decisions/show/67621530.

12. Постанова Великої Палати Верховного Суду від 04 липня 2018 року у справі № 653/1096/16-ц / Верховний Суд України. URL: http://reyestr.court.gov.ua/Review/75296538.

13. Постанова Касаційного цивільного суду у складі Верховного Суду від 06 березня 2018 року у справі № 607/15489/15-ц / Верховний Суд України. URL: http:// reyestr.court.gov.ua/Review/73001005.

14. Постанова Великої Палати Верховного Суду від 04 липня 2018 року у справі № 653/1096/16-ц / Верховний Суд України. URL: https://kma.court.gov.ua/sud4820/ gromadyanam/1/vyselenia. 